\title{
Yellow Sap Contamination on Mangosteen (Garcinia mangostana L.) Fruit in Relation to Soil Calcium Contents and Plant Tissue
}

\author{
Martias ${ }^{1}$, Titin Purnama ${ }^{1}$, Riska $^{1}$, Affandi ${ }^{1}$, Sri Yuliati ${ }^{1}$, Nini Marta ${ }^{1}$, \\ Tri Budiyanti' ${ }^{1}$, Deni Emilda ${ }^{1}$, Dewi Fatria ${ }^{1}$, Hendri', I. G. K. D. Arsana ${ }^{2}$, \\ Ratna W. Arief ${ }^{3}$, Robet Asnawi ${ }^{3}$ and Made J. Mejaya ${ }^{4 *}$ \\ ${ }^{1}$ Indonesia Tropical Fruits Research Institute, Indonesia, Jl. Raya Solok-Aripan Km. 8, Solok \\ 27301, West Sumatra, Indonesia. \\ ${ }^{2}$ Bali Assessment Institute for Agricultural Technology, Jl. By pass Ngurah Rai No.1A, Denpasar \\ 80222, Bali, Indonesia. \\ ${ }^{3}$ Assessment Institute for Agriculture Technology of Lampung. Jl. Z.A. Pagar Alam No. 1 A, Bandar \\ Lampung City35145, Lampung, Indonesia. \\ ${ }^{4}$ Indonesian Legumes and Tuber Crops Research Institute (ILETRI), JI. Raya Kendakpayak Km 8 PO \\ Box 66, Malang 65101, East Java, Indonesia.
}

Authors' contributions

This work was carried out in collaboration among all authors. Authors M, A, SY, TP, NM and TB designed the study. Authors $M, R, A, S Y$ and NM performed the statistical analysis and wrote the protocol. Authors M, TP, DE, DF, IGKDA, RA and MJM wrote the first draft of the manuscript. Author $M, S Y, T P, N M, D E$, and DF managed the analyses of the study. Authors $M, T P, D E, D F, I G K D A$, $R W A, R A$ and MJM managed the literature searches. All authors read and approved the final manuscript.

\section{Article Information}

DOI: $10.9734 / A R R B / 2021 / v 36 i 930418$ Editor(s):

(1) Dr. Rishee K. Kalaria, Navsari Agricultural University, India. Reviewers:

(1) Abdul Awal Chowdhury Masud, Sher-e-Bangla Agricultural University, Bangladesh. (2) Kadhim M. Ibrahim, Al-Nahrain University, Iraq. Complete Peer review History: https://www.sdiarticle4.com/review-history/72516

Original Research Article

Received 20 June 2021

Accepted 27 August 2021 Published 01 September 2021

\section{ABSTRACT}

Yellow sap contamination (YSC) is one of the mangosteen quality constrain in Indonesia. Calcium is the prominent nutrient that influence the incidence of yellow sap contamination. A research with objective to observe the relationship between incidence YSC and $\mathrm{Ca}$ availability in soil as well as 
plant tissue was done in ten locations in West Sumatra, Lampung and West Java provinces. Purposive random sampling method was used to determine the site locations. The plant and soil samples were collected from 10 sites and ten tree per sites. Correlation analysis was used to measure the relationship between incidence YSC and $\mathrm{Ca}$ content in fruit endocarp, mesocarp, peel, soil and leaf. The result showed that there was a variation of incidence YSC in site location with range of $8.7 \%-54.04 \% ; 4.0-51.6 \%$; and $17.7-78.6 \%$ for percentage of YSC in fruit flesh, segmentation and peel, respectively. Ca content in soil, endocarp, mesocarp and leaf were given significantly negative correlation toward incidence YSC in fruit flesh and segmentation. Ca content in leaf part correlates significantly to $\mathrm{Ca}$ availability in soil, endocarp and mesocarp. Ca content in leaf in the range of $1.40-1.70 \%$ indicates YSC less than $10 \%$.

Keywords: Yellow sap; calcium; soil; plant tissue; mangosteen.

\section{INTRODUCTION}

Yellow sap contamination is the most prominent barrier for low quality and export of Indonesian mangosteen. Yellow sap contamination on mangosteen fruit is caused by emerging of yellow sap due to broken sap of capillary. Yellow sap capillary on mangosteen fruit exists in the fruit endocarp, mesocarp, axocarp and flesh (Dorly 2009). Lack of Calcium (Ca2+) content breaks the sap capillary of mangosteen fruit, especially during fruit development, fluctuation of turgor, seasonal climate transitions from dry to the rainy season $[1,2]$.

Ca plays an important role in the structure cell wall as Ca-Pectate in the middle lamella, regulate and keep stability of the membrane $[3,4]$. Calcium is prominent component which determine mechanical character of plant tissue [5]. Calcium is considered as mineral which plays an important role in controlling physiological process, fruit quality as well as freshness of the fruit [6]. Calcium is also functioned as regulator for membrane and wall cell stability, plant cell integrity as well as biotic and abiotic stress $[7,8,9]$. Cation $\mathrm{Ca} 2+$ is also needed to guard cell wall, membrane structure and in the vacuole functioning as counter-cation for anion of anorganic and organic [10]. Cal contributes in structure and function of cellular membrane which bundle to phospholipid and protein in the membrane surface [7]. Part of polysaccharide called pectic rhamnogalacturonan of middle lamella is connected by ion $\mathrm{Ca}$. Plant requires high amount of $\mathrm{Ca}$ and its' accumulation is up to $1 \%$ in dry materials could more than $0.1-1.0 \%$ $[10,4]$.

Application of $\mathrm{Ca} 2+$ before and after harvesting could maintain cell turgor, membrane plasma integrity, freshness and prolong fruit self-life $[11,12]$. Ca deficiency can cause physiological disorder and decline fruit quality $[13,1,5]$. The deficiency of $\mathrm{Ca} 2+$ led to the disintegration of the cell wall and died of plant tissue. Ca deficiency on Lychee caused fruit peel cracking [5]. Several studies reported that $\mathrm{Ca}$ application minimizes YSC on mangosteen... Direct spraying of $\mathrm{Ca}$ declines the score of YSC on aril fruit; however, its application through soil does not give significantly impact. $[14,15,16,17]$. Pechkeo et al. [17] reported that spraying of mangosteen fruit with $10 \% \mathrm{CaCl} 2$ increase normal fruits and decrease yellow sap contamination as well as translucent. Martias et al. [18] stated that the percentage of yellow sap contamination was determined by the availability of $\mathrm{Ca}$ in soil.

Various severity of yellow sap contamination was found in mangosteen central production with different agro-climate. Further, agro-climate zone determines the availability of $\mathrm{Ca}$ in soil $[19,20,21]$. The availability of $\mathrm{Ca}$ in soil which supported by $\mathrm{Ca}$ content in plant is an important role in controlling yellow sap contamination. The objectives of the research was to study the variability of yellow sap contamination in of several mangosteen central production in Indonesia and to estimate the correlation among $\mathrm{Ca}$ availability in soil and plant toward yellow sap contamination severity.

\section{MATERIALS AND METHODS}

The research was conducted in several mangosteen production center in West Sumatra, Lampung, and West Java provinces of Indonesia which were chosen based on wide área and productivity of mangosteen [22]. Distric location was selected based on information from Provincial Agriculture Office. Purposive sampling technique was used to interview sub-district trader to determine mangosteen center production in village. Ten locations were selected for research namely Nagari Koto Lua, Baringin 
(Padang City), Pakandangan (Padang Pariaman District), Padang Laweh, Lalan (Sijunjung District) in West Sumatra, Desa Suka Rame (Lampung Barat City) in Lampung province, Desa Karacak and Barengkok (Bogor district), Desa Garogek and Pusaka Mulia (Purwakarta District) in West Java province.

\subsection{Soil and Plant Materials}

The mangosteen plants were chosen as sample represented yellow latex contamination problem, age and plant vigority. The plant ages were ranged from $30-35$ year and have been producing fruits. Ten plants were selected for each location and 100 fruits were harvested from each plant. Hence, totally 10,000 mangosteen fruits had been harvested and observed.

Soil samples were collected by using composite sample technique under plant canopy at four cardinal directions as well as in the center of the orchard. Fully developed leaves from terminal twigs were sampled to determine $\mathrm{Ca}$ content on leaf. The leaf samples were collected from four cardinal directions. Fruit samples were harvested when fruits were physiologically matured at stage 2 [23].

The parameters were observed involve: (a) The percentage of the fruit flesh was contaminated by yellow sap, (b) The percentage of fruit separator was contaminated by yello sap, (c) The percentage of fruit peel was contaminated by yellow sap, (d) The availability of $\mathrm{Ca}$ content in the soil, leave and peel (mesocarp and endocarp).

\subsection{Observation on Parameter Yellow Sap Contamination}

The observed parameters were: (a) the percentage of the fruit flesh was contaminated by yellow sap, (b) the percentage of fruit separator was contaminated by yellow sap, (c) the percentage of fruit peel was contaminated by yellow sap, and (d) the availability of Ca content in the soil, leave and peel (mesocarp and endocarp).

Yellow sap contamination was observed manually in each fruit on flesh, fruit separator (segment) as well as fruit peel. The percentage of aril contaminated by yellow latex (PACbYL), fruit segment (PSCbYL), and fruit peel (PPCbYL) were counted based on formula:
The level of yellow sap contamination in fruit flesh, segment and peel were determined based on category presented in Table 1 below:

\subsection{Analysis of Ca Availability in Soil}

Ten samples of soil were taken in each location of the research. The soil was excavated in the depth of $0-30 \mathrm{~cm}$ in the distance of $3 \mathrm{~m}$ from tree stem. The soil sample was air dried and grinded in the mesh of $<5 \mathrm{~mm}$ before analyzed in the laboratory.

The grinded soil was weighed $2.50 \mathrm{~g}$ then mixed with quartz sand. Further, the mix material was inserted in percolation tube that was coated by filter flock and sand, respectively. Then, the material was percolated with amonium acetat $\mathrm{pH}$ 7,0 with amount of $2 \times 25 \mathrm{ml}$ and interval 30 minutes. The Filtrat was collected in volumetric flask $50 \mathrm{ml}$, then crashed by amonium acetat $\mathrm{pH}$ 7,0 to measure $\mathrm{Ca}$ contain that could be exchanged. The percolate $\mathrm{NH} 4-\mathrm{Ac}(\mathrm{S})$ and row standard $\mathrm{Ca}$ was pipetted $1 \mathrm{ml}$ into test tube, then added $9 \mathrm{ml}$ La $0,25 \%$ solution and measured by AAS machine [24].

\subsection{Analysis of Ca Availability in Leaves, Endocarp and Mosocarp of Fruit Peel}

Sample of leaves, endocarp and mesocarp was sifted in measurement $<0,5 \mathrm{~mm}$ then $0,50 \mathrm{~g}$ was put into digestion tube. Further, add $5 \mathrm{ml}$ HNO3 p.a. and $0,5 \mathrm{ml} \mathrm{HCLO} 4$ p.a. and soak for 24 hours. Next, the materials were heated in digestion block at temperature $100 \mathrm{oC}$ for 1 hour, then, the temperature was inclined to $150 \mathrm{oC}$. Destruction process was done after white smoke released and the remain of the extract more or less than $0,5 \mathrm{ml}$. Then, light up the tube and let it be cool. The extract was diluted with non-ionic water till the volume being $50 \mathrm{ml}$ and shake with tube shaker hence the solution homogen. This extraction was used to measure $\mathrm{Ca}$ availability in leaves, endocarp and mesocarp. One (1) $\mathrm{ml}$ extract and standart solution was pipeted, then added with $9 \mathrm{ml}$ La $0,25 \%$ solution. The solution then measure by utilizing SSA [24].

To estimate the effect of $\mathrm{Ca}$ availability in soil, endocarp, mesocarp and leave toward the incidence of yellow sap contamination, regression analysis was utilized. 


$\begin{array}{llll}\text { PACbYL } & =\frac{\text { Number of fruit aril was contaminated by yellow latex }}{\text { Number of fruits were observed }} & \text { X } & \\ \text { PSCbYL } & = & \begin{array}{l}\text { Number of fruit segment was contaminated by yellow latex } \\ \text { Number of fruit segment was observed }\end{array} \\ \text { PPCbYL } & =\frac{\text { Number of fruit peel was contaminated by yellow latex }}{\text { Number of fruits were observed }}\end{array}$

Table 1. The percentage level of yellow sap contamination on mangosteen fruit

\begin{tabular}{ll}
\hline Category & Percentage \\
\hline Very low & $0-10$ \\
Low & $>10-20$ \\
Medium & $>20-30$ \\
Less high & $>30-40$ \\
High & $>40-50$ \\
Very high & $>50-100$ \\
\hline
\end{tabular}

\section{RESULTS AND DISCUSSIONS}

\subsection{Variability of Yellow Sap Contamination}

Mangosteen fruit from ten different production centers turned out to be the percentage of fruit that was contaminated with yellow latex, whether it came from the same district or municipality or different. The percentage of arils contaminated with yellow latex was classified as very high, found in Pakandangan and Sukarame, reaching $60.90 \%$ and $52.10 \%$, respectively, while the high category was found in Garoge, which was $40.60 \%$. The percentage of arils contaminated with yellow latex was classified as moderate from Karacak and Garoge, 25.20\%, 24.10\%, respectively. Only at two locations obtained PGKA classified as low, namely Koto Lua and Baringin (18.20\% and $18.91 \%)$, and included in the very low category obtained in Padang Laweh and Lalan $(10.40 \%$ and $9.60 \%$ (Fig. 1 ).

The percentage of yellow gummy juice as an indicator of the severity of the gummy mangosteen pulp for each fruit also varies at different locations. The percentage of yellow gummy juring is classified as very high, obtained in Garoge, reaching $51.60 \%$. Locations classified as high in PJGK were found in Karacak, Barengkok, Sukarame, and Nagari Pakandangan ranging from $40.50 \%$ to $50.10 \%$. Nagari Koto Lua, Baringin, Padang Laweh and Lalan are locations that have a very low percentage of yellow gum, ranging from 4.00 to $7.70 \%$ (Fig. 1).
Most of the mangosteen fruit obtained from the ten production centers was contaminated with yellow sap on the skin. The percentage of fruit contaminated with yellow latex was classified as very high from Sukarame, Lalan, Pakandangan, Karacak, Padang Laweh, Barengkok, Baringin, Pakandangan, ranging from $64.50 \%-88 \%$. Only at two locations that were classified as low the percentage of fruit contaminated with the yellow sap part of the skin, namely Pusaka Mulia and Garoge, was $16.10 \%$ and $17.70 \%$, respectively (Fig. 1).

Several categories of yellow sap contamination were found in Pakandangan, Sukarame, and Garogek which mostly exhibited high to very high yellow sap contamination in fruit flesh, segmentation and peel. A complete percentage of yellow sap contamination in each mangosteen center production was presented in Fig. 1.

A very high percentage of yellow sap contamination on mangosteen fruit flesh (PACbYL) was found Pakandangan and Sukarame that reached $60.90 \%$ and $52.10 \%$, respectively. Meanwhile high categorize was discovered in Garogek as high as $40.60 \%$. The percentage of yellow sap contamination on fruit segmentation (PSCbYL) was found very high in Pakandangan and Sukarame $(51.60 \%)$. On the high percentage was discovered in Garogek, medium was Karacak and Barengkok. Low were Pusaka Mulia, Koto Lua, Lalan, and Beringin. Further, a very low percentage of yellow sap contamination on fruit peel was found in Padang Laweh. 


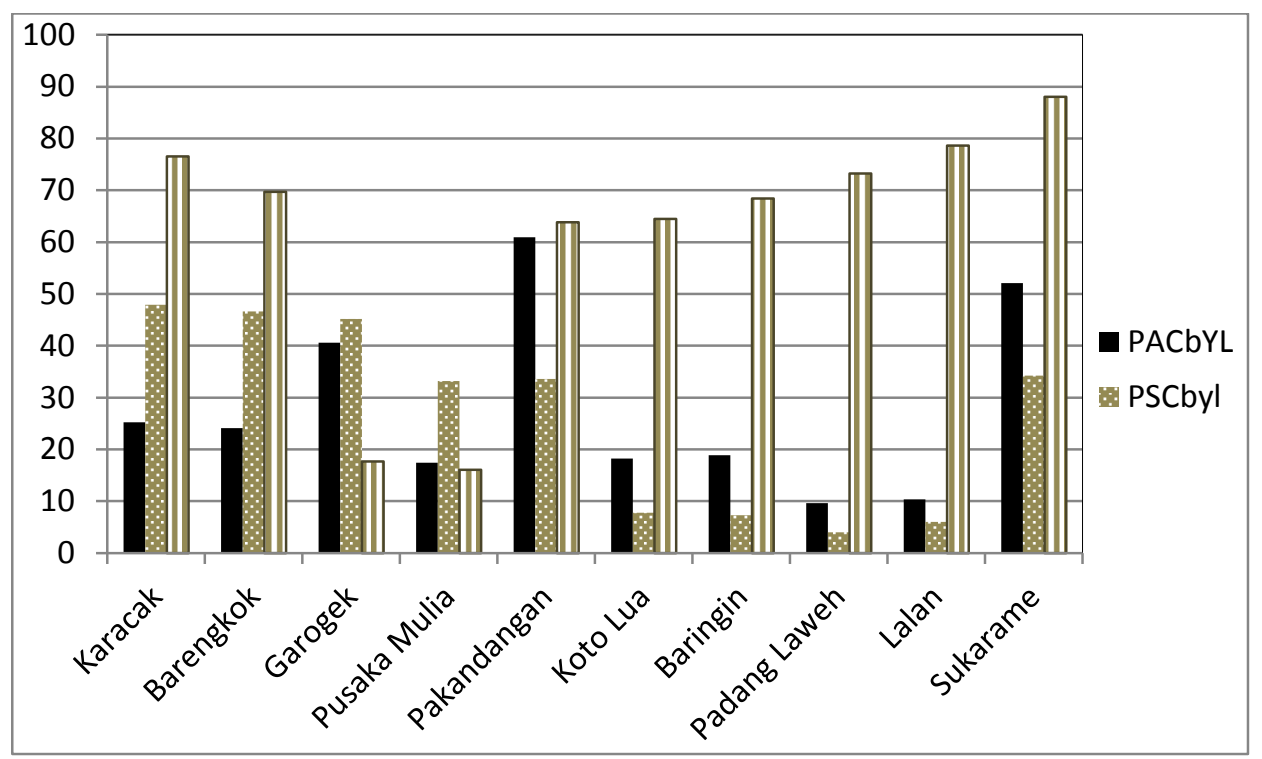

Fig. 1. Performance of aryl sap contamination, segments, and mangosteen rind in several mangosteen production centers

A medium to low percentage of yellow sap contamination on fruit flesh was found in several mangosteen production center such as Karacak (25.20\%), Garogek (24.10\%), Koto Lua (18.20\%), Baringin (18.91\%), Padang Laweh $(10.40 \%)$ and Lalan (9.60\%). Yellow sap contamination on segmentations were found in Koto Lua, Baringin, Padang Laweh and Lalan which low categorize ranged from 4.00 to $7.70 \%$. Low percentage of yellow sap contamination on fruit peel was found in Pusaka Mulia (16.10\%) and Garogek (17.70\%).

The variation of yellow sap contamination indicated that environment influence the incidence of contamination in fruit flesh, segmentation and peel. Similar research informed that incidence of yellow sap contamination was influenced by environment such as climate and $\mathrm{Ca}$ availability $[23,2,24,25,1]$. The research by Jawal et al. [26] showed that application of water continuously during fruiting stages reduce the incidence of yellow sap contamination till $36 \%$ inside the fruit peel. Among those environmental factors, $\mathrm{Ca}$ availability affected directly on emersion of yellow sap contamination [19].

\subsection{Relationship Between Yellow Sap Contamination and $\mathrm{Ca}$ Availability in Soil and Plant Tissue}

The percentage of yellow sap contamination was found in fruit flesh and segmentation significantly gave negative correlation to $\mathrm{Ca}$ availability in soil, mesocarp and leaf. A complete correlation analysis was presented in Table 2.

The regression analysis showed that there was an exponential relationship between percentage of yellow sap contamination on fruit flesh and $\mathrm{Ca}$ availability in soil (Figure 2). The decline the percentage of percentage of yellow sap contamination on fruit flesh was affected by incline of $\mathrm{Ca}$ availability in soil. The percentage of fruit flesh contaminated by yellow sap $<10 \%$ was given by $\mathrm{Ca}$ availability in soil more than 20 $\mathrm{Cmol}(+) / \mathrm{kg}-1$ ). Calsium availability in soil $10-20$ Cmol (+)/kg-1) indicated increase of PACbYL till $30 \%$ and the trend will increase up to $70 \%$ in $\mathrm{Ca}$ availability in soil less than $10 \mathrm{Cmol}(+) / \mathrm{kg}-1)$. The correlation between CA availability in the soil and incidence of yellow sap contamination on fruit flesh (PACbYL) indicated that $\mathrm{Ca}$ availability in soil play an important role.

Ca availability on endocarp was also influencing the incidence of yellow sap contamination in fruit flesh (PACbYL). Low Ca availability in endocarp correlated to high percentage of yellow sap contamination in fruit flesh. Correlation analysis between $\mathrm{Ca}$ availability and percentage of yellow sap contamination incidence was exhibited in Fig. 3.

The research found that very high percentage of fruits $(70 \%)$ were contaminated by yellow sap in $<0.15 \%$ of $\mathrm{Ca}$ content in endocarp. Meanwhile, only $30 \%$ fruits were contaminated by yellow sap 
in $30 \% \mathrm{Ca}$ content in endocarp. This result indicated that $\mathrm{Ca}$ content in endocarp tissue contributed in minimalizing incidence of yellow sap contamination, since Ca play an important role to strengthen wall cell capillary of yellow sap.

The incidence of yellow sap contamination in fruit flesh (PBAGK) was also determined by $\mathrm{Ca}$ availability in mesocarp. High percentage of fruits flesh was contaminated by yellow sap $(70 \%)$ in low $\mathrm{Ca}$ content in mesocarp (< $0.15 \%)$ ). Meanwhile, Ca content in mesocarp ( $>15 \%$ ) only cause $15 \%$ contaminated with yellow sap. Correlation analysis between $\mathrm{Ca}$ content in mesocarp and incidence of yellow sap contamination was pointed in Fig. 4.

Table 2. Correlation between the percentage of yellow sap contamination on fruit flesh and fruit segmentation with $\mathrm{Ca}$ availability in soil, endocarp, mesocarp and leaf

\begin{tabular}{lllll}
\hline & Ca -soil & Ca endocarp & Ca mesocarp & Ca leaf \\
\hline PACbYL & $-0.509^{* *}$ & $-0.524^{\star *}$ & $-0.538^{\star *}$ & $-0.691^{* *}$ \\
PSCbYL & $-0.644^{* *}$ & $-0.337^{\star *}$ & $-0.334^{* *}$ & $-0.474^{* *}$ \\
\hline
\end{tabular}

Note: $P A C b Y L=$ Percentage of yellow sap contamination of fruit flesh, $P S C b Y L=$ Percentage of yellow sap contamination of fruit segmentation, PPCbYL = Percentage of yellow sap contamination of fruit peel

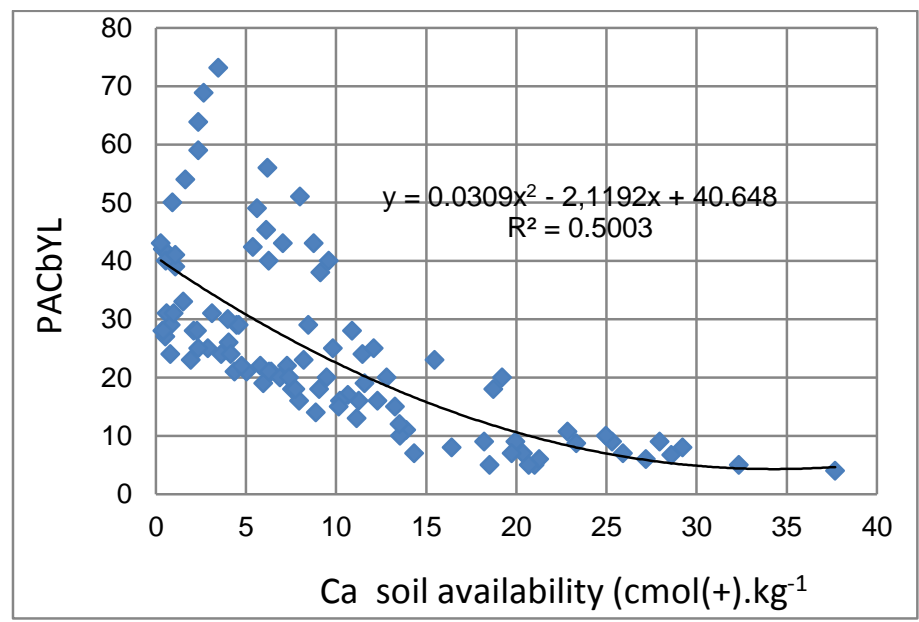

Fig. 2. The relationship of the percentage of yellow sap contamination on fruit flesh with $\mathrm{Ca}$ availability in soil in several mangosteen productions center in Indonesia

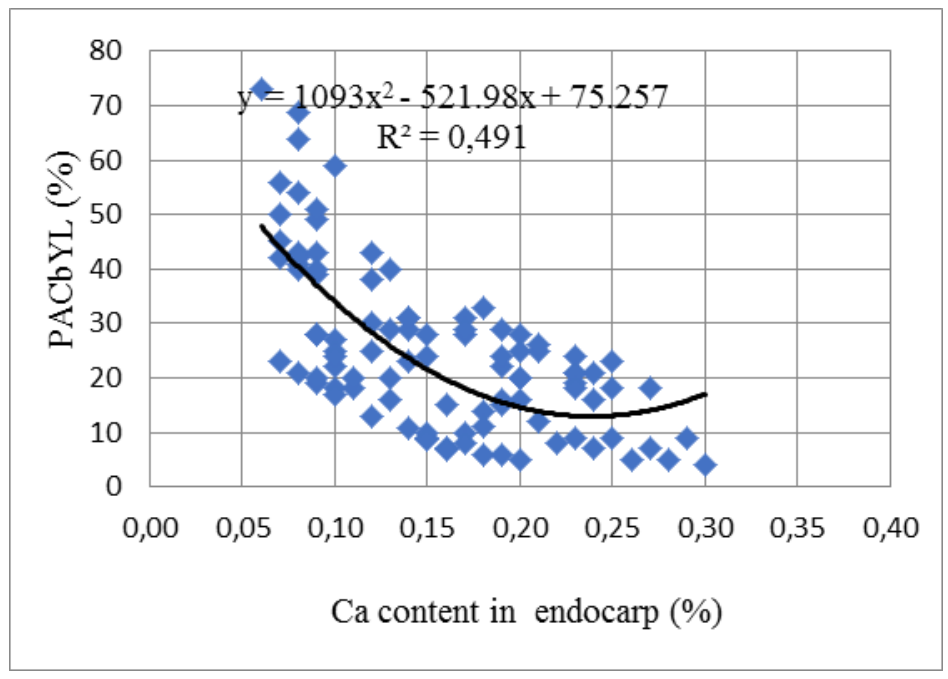

Fig. 3. The correlation of $\mathrm{Ca}$ content in endocarp toward percentage of yellow sap contamination incidence (PACbYL) 


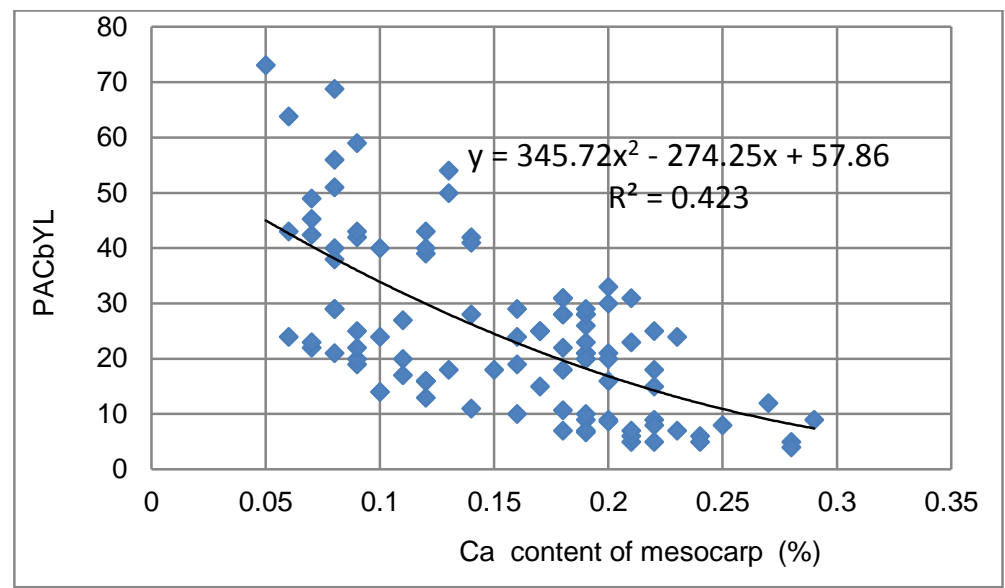

Fig. 4. The correlation of Ca content in mesocarp toward percentage of aryl yellow sap contamination (PACbYL)

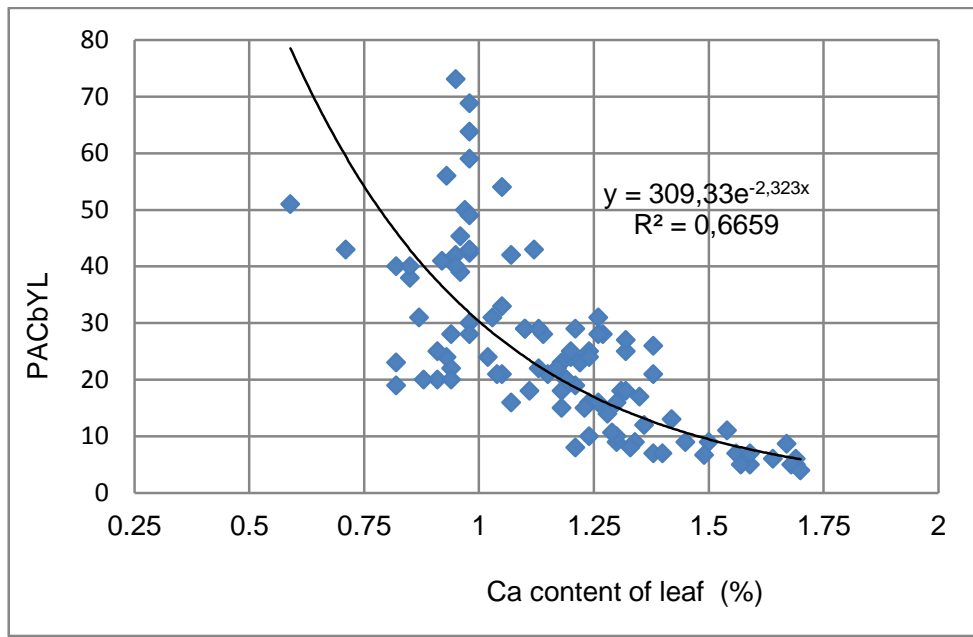

Fig. 5. The correlation of $\mathrm{Ca}$ content in leaf toward percentage of yellow sap contamination incidence (PACbYL)

Table 3. The correlation between yellow sap contamination incidence and Ca availability in soil, endocarp, mesocarp and leaf

\begin{tabular}{lllll}
\hline & Ca in soil & Ca endocarp & Ca mesocarp & Ca leaf \\
\hline Ca in soil & 1 & $0.281^{\star *}$ & $0.332^{\star \star}$ & $0.415^{\star \star}$ \\
Ca in endocarp & & 1 & $0.820^{\star \star}$ & $0.709^{\star \star}$ \\
Ca in mesocarp & & 1 & $0.709^{\star \star}$ \\
\hline
\end{tabular}

Regression analysis informed that $\mathrm{Ca}$ content in leaf was given exponential relationship to percentage of yellow sap contamination incidence. Very high percentage of fruits flesh were contaminated by yellow sap (70\%) in $\mathrm{Ca}$ content of $<1 \%$ in leaf. Meanwhile, Ca content in leaf ranged of $1-1.25 \%, 1.25 \%-1.5 \%, 1.5 \%$ $1.75 \%$ were exhibited $10-40 \%, 6-30 \%$ and $6-10 \%$ fruits contaminated by yellow sap, respectively. Correlation between $\mathrm{Ca}$ content in leaf and incidence of yellow sap in fruit flesh presented in Fig. 5.

The accumulation of $\mathrm{Ca}$ content in leaf was higher than in endocarp and mesocarp tissue and reached of $1.70 \%$. Leaf $\mathrm{Ca}$ levels ranged from $0.59 \%-1.70 \%$, while in endocarp and mesocarp only $0.06 \%-0.31 \%$ and $0.05 \%-0.29 \%$, respectively (Figs. 3, 4, 5). Calsium was absorbed and translocated to plant tissue 
through mass flow method and most of the accumulation was available in the tissue which active in transpiration activities such as leaves. Hence, it is logically if the Ca content was high in leaf compared to mesocarp and endocarp. The relationship pattern of $\mathrm{Ca}$ content in leaf, mesocarp and endocarp was inline in causing yellow sap contamination incidence in 10 research locations. The research indicated that $\mathrm{Ca}$ content in leaf representative as indicator for yellop sap contamination in fruit flesh of mangosteen.

\subsection{The Relationship of Ca Availability in soil with $\mathrm{Ca}$ Content in leaf, Mesocarp and Endocarp}

$\mathrm{Ca}$ availability in the leaf, mesocarp and endocarp was corelated positively and significantly to $\mathrm{Ca}$ content in soil (Table 3). $\mathrm{Ca}$ availability in endocarp and mesocarp tissue was also indicated significantly positive correlation to $\mathrm{Ca}$ content in the leaf with the values of 0.82 and 0.71 , respectively. This coefficient correlation showed that $\mathrm{Ca}$ content in endocarp, mesocarp and leaves tissue correlated with $\mathrm{Ca}$ content in soil. A very high correlation was given by $\mathrm{Ca}$ content among tissue of endocarp, mesocarp and leaf. The correlation of $\mathrm{Ca}$ content in endocarp, mesocarp and leaf are understandable since soil is the main source of Calcium. Calcium is absorbed by root from soil through mass flow mechanism and translocated to all parts of plant tissue [3]. High and significantly correlation between $\mathrm{Ca}$ content in leaf to $\mathrm{Ca}$ content in endocarp and mesocarp indicated that accumulation of $\mathrm{Ca}$ content in leaf represent of nutritional condition in mangosteen fruit. Significant correlation between $\mathrm{Ca}$ content in leaf and soil indicated that $\mathrm{Ca}$ content in leaf could be used to predict $\mathrm{Ca}$ content in the soil. The result indicated that $\mathrm{Ca}$ content in the leaf could be used to predict $\mathrm{Ca}$ content of plant and soil in relation to yellow sap contamination. Further, early detection on availability of yellow sap contamination could be done and agricultural action could be applied to prevent more severity impact.

Yellow sap capilarity is available in all parts of the mangosteen plant except in root. In mangosteen fruit yellow sap capilarity is found in fruit flesh (aryl), inside part of the peel (endocarp), meddle part of the peel (mesocarp) and outside peel (exocarp) [2]. Yellow sap capilarity that having potential to broke and cause contamination on fruit flesh is endocarp and mesocarp. The strengthen of cell wall in endocarp and mesocarp determine number of broken yellow sap capilarity. Calcium is a prominent nutrition which arrange cell wall and determine it strength [3]. Calcium deficiency could induce the rapture of cell wall then yellow sap will flood to the fruit flesh. The damage and death of cell is related to leaking of plasma membrane which contain ion $\mathrm{Ca} 2+$ [27]

\section{CONCLUSIONS}

Variation occurs in incidence of yellow sap contamination in fruit flesh, segmentation, and peel in 10 locations of the research with range of $8.7 \%-54.04 \%$; 4.0-51.6 \%; dan 17.7-78.6\%, respectively. Ca availability in soil, endocarp and mesocarp tissue as well as leaf were negatively correlated to incidence of yellow sap contamination in fruit flesh and segmentation. $\mathrm{Ca}$ availability in leaf positively correlated to $\mathrm{Ca}$ availability in soil, endocarp and mesocarp. $\mathrm{Ca}$ availability in leaf with range of $1.40-1.70 \%$ was the ideal content to decline percentage of mangosteen fruit contaminated by yellow sap less than $10 \%$.

\section{COMPETING INTERESTS}

Authors have declared that no competing interests exist.

\section{REFERENCES}

1. Poerwanto R, Dorly, Martias. Getah kuning pada buah manggis dalam Reorientasi Riset untuk Mengoptimalkan Produksi dan Rantai Nilai Hortikultura. Seminar Nasional Hortikultura, 25-26 Januari 2010. Perhimpunan Hortikultura Indonesia. Dempasar Bali. 2010;255-260:2.

2. Dorly S. Studi struktur sekretori getah kuning dan pengaruh kalsium terhadap cemaran getah kuning pada buah manggis (Garcinia mangostana L.). [Disertasi]. Bogor. Institut Pertanian Bogor; 2009.

3. Marschner $\mathrm{H}$. Mineral in higher plants. Academic press, New York. 1995.

4. White, PJ, Broadley, MR. Calcium in plants. Ann. Bot. 2003;92:487-511.

5. Huang $X$, Wang HC, Li J, Yuan W, Lu J, Huang HB. An overview of calcium's role in lychee fruit cracking. Acta. Hort. 2005;66(5):231-240.

6. Lurie S. Stress physiology and latent damage. In: Florkowski WJ, Shewfelt RL, 
Brueckner B, Prussia SE. (Eds.), Postharvest Handling: A Systems Approach. Academic Press 2009;443459.

7. Hirschi KD. The calcium conundrum. Both versatile nutrient and specific signal. Plant Physiol. 2004;136:2438-2442.

8. Marry M, Roberts K, Jopson SJ, Huxham $I M$, Jarvis MC, Corsar J, Robertson E, McCann MC. Cell-cell adhesion in fresh sugar-beet root parenchyma requires both pectin esters and calcium cross-links. Physiol. Plant. 2006;126:243-256.

9. Hepler PK. Calcium: a central regulator of plant growth and development. Plant Cell. 2005;17:2142-2155.

10. White PJ. The pathways of calcium movement to the xylem. Journal of Experimental Botany. 2001;52:891899.

11. Gerasopoulos D, Chouliaras V, Lionakis S. Effects of preharvest calcium chloride sprays on maturity and storability of Hayward kiwifruit. Postharvest Biol Technol. 1996;7:65-72.

12. Miklus MB, Beelman RB. CaC12 treated irrigation water applied to mushroom crops (Agaricus bisporus) increases $\mathrm{Ca}$ concentration and improves postharvest quality and shelf life. Mycologia. 1996;88:403-409.

13. Pludbuntong W, Makhonpas C, Poovarodom S. Nutrient content in translucent flesh and gamboge disorders of mangosteen fruits (Garcinia mangostana L.). International Conference on Integration of Science \& Technology for Sustainable Development. 26-27 April, 2007. Bangkok, Thailand. 2007;30-34.

14. Dorly, Soekisman T, Jaime A. Silva T, Poerwanto R, Efendi E, Febriyanti B..Calcium spray reduces yellow latex on mangosteen fruit (Carcinia mangostana L). Journal of Fruit and Ornamental Plant Research. 2011;19(2):51-65.

15. Odit FK, Depari SOS, Poerwanto R, Efendi D. Solving yellow sap contamination problem in mangosteen (Garcinia mangostana) with $\mathrm{Ca}^{2+}$ application based on fruit growth stage. Communications In Biometry And Crop Science. 2016;11(2): 105-113.

16. Tanari Y, Efendi D, Poerwanto R,
Sopandie D, Suketi K. Yellow sap contamination at different. Adv. Hort. Sci. 2018; 32(2):169-175.

17. Pechkeo S, Sdoodee S, Nilnond C. The Effects of calcium and boron sprays on the incidence of translucent flesh disorder and gamboge disorder in mangosteen (Garcinia mangostana L.). Kasetsart J. Nat. Sci. 2007;41:621-632.

18. Martias, Poerwanto R, Anwar S, Hidayati R. Hubungan ketersediaan hara tanah dengan cemaran getah kuning pada buah manggis. Jur. Hort. 2012;22(2):111-119.

19. Martias. Studi Peranan Lingkungan (Sifat Kimia dan Fisika Tanah serta Cuaca) terhadap Cemaran Getah Kuning Buah Manggis (Garcinia mangostana L.). [Disertasi]. Bogor. Institut Pertanian Bogor; 2012.

20. Gunawan E. Hubungan agroklimat dengan fenofisiologi tanaman dan kualitas buah manggis di lima sentra produksi di pulau Jawa [Tesis]. Bogor. 2007.

21. Liferdi. Diagnosis status hara menggunakan analisis daun untuk menyusun rekomendasi pemupukan pada tanaman manggis (Garcinia mangostana L.). [Disertasi]. Bogor: Institut Pertanian Bogor; 2007.

22. Direktorat Jenderal Hortikultura. Tanaman Menghasilkan, Luas Panen, Hasil per Hektar, Hasil per Pohon dan Produksi Manggis menurut Provinsi. Direktorat Jenderal Hortikultura, Kementerian Pertanian; 2011.

23. Dorly, Tjitrosemito $S$, Poerwanto $R$, Juliarni. Secretory duct structure and phytochemistry compouns of yellow latex in mangosteen fruit. HAYATI Journal of BioScience 2008;15:99-104.

24. Febriyanti B. Pengaruh penyemprotan kalsium klorida terhadap kondisi getah kuning buah manggis (Garcinia mangostana L.). [Skripsi]. Bogor. Institut Pertanian Bogor. 2009.

25. Wulandari I. Pengaruh aplikasi kalsium terhadap getah kuning pada buah manggis (Carcinia mangostana L.). [Skripsi]. Bogor. Institut Pertanian Bogor. 2009.

26. Jawal M, Anwarudin S, Mansyah E, Martias, Purnama T, Fatria D, Usman F. Pengaruh pemberian air dan pemupukan 
terhadap getah kuning pada buah manggis. J. Hort. 2010; 20(1):10-17.

27. Arora R, Palta JP. Protoplasmic swelling as a symptom of freezing injury in onion bulb cells. Plant Physiol. 1986;82:625629

(0) 2021 Martias et al.; This is an Open Access article distributed under the terms of the Creative Commons Attribution License (http://creativecommons.org/licenses/by/4.0), which permits unrestricted use, distribution, and reproduction in any medium, provided the original work is properly cited.

Peer-review history:

The peer review history for this paper can be accessed here:

https://www.sdiarticle4.com/review-history/72516 